CHANGE AND THE MODERN BUSINESS 
Also by Neil Harris

EUROPEAN BUSINESS 


\section{CHANGE AND THE MODERN BUSINESS}

Edited by

Neil Harris 
Selection, editorial matter and Chapter 2 (C) Neil Harris 1997

Individual chapters (in order) (C) John Cross, Gary Akehurst, Richard Thomas, Ashok Ranchhod, Brian Thornton, Heather Stewart, Adrian Webb, Mark Wing, Mervyn Rowlinson 1997

All rights reserved. No reproduction, copy or transmission of this publication may be made without written permission.

No paragraph of this publication may be reproduced, copied or transmitted save with written permission or in accordance with the provisions of the Copyright, Designs and Patents Act 1988, or under the terms of any licence permitting limited copying issued by the Copyright Licensing Agency, 90 Tottenham Court Road, London W1P 9HE.

Any person who does any unauthorised act in relation to this publication may be liable to criminal prosecution and civil claims for damages.

The authors have asserted their rights to be identified as the authors of this work in accordance with the Copyright, Designs and Patents Act 1988.

First published 1997 by MACMILLAN PRESS LTD

Houndmills, Basingstoke, Hampshire RG21 2XS and London

Companies and representatives throughout the world

ISBN 978-0-333-68092-6

A catalogue record for this book is available from the British Library.

$\begin{array}{rrrrrrrrrr}10 & 9 & 8 & 7 & 6 & 5 & 4 & 3 & 2 & 1 \\ 06 & 05 & 04 & 03 & 02 & 01 & 00 & 99 & 98 & 97\end{array}$

Copy-edited and typeset by Povey-Edmondson

Tavistock and Rochdale, England 


\section{Contents}

List of figures

List of tables

Notes on the contributors

Introduction

List of abbreviations

1 Modern developments in business strategy 1 John Cross

1.1 Introduction 1

1.2 Strategy and change in practice 2

1.3 The changing environment 8

1.4 Frameworks for analysing internal capability 11

1.5 Stakeholder mapping 16

1.6 Strategic options and choice 18

1.7 Case study: Générale des Eaux (GDE) 22

1.8 Using frameworks on the GDE case study 29

1.9 Conclusions 38

Questions for discussion 39

Bibliography 40

2 The economics of organisational change 41

Neil Harris

2.1 Introduction 41

2.2 Why organisations change - rationale and implications 41

2.3 The financial services sector of the UK economy 43

2.4 The structure - conduct - performance methodology 49

2.5 Structure 49

2.6 Conduct 60

2.7 Acquisitions, mergers and diversification - market-driven change 63

2.8 Performance 68

2.9 Criticisms of the structure - conduct - performance methodology 71 
2.10 Conclusions: the financial services sector - which way forward? 72 Questions for discussion 73

Bibliography 74

3 Services management 76

Professor Gary Akehurst

3.1 Introduction: The growth of the service economy 76

3.2 What is services management? 83

3.3 Designing service products and their management 85

3.4 Defining service quality and how it can be promoted 90

3.5 Service encounters, service personnel and recovery from service failures 94

3.6 Strategic services management - the strategy of the augmented service 98

3.7 Case study: Brownloaf MacTaggart - the next chapter in a sorry saga 100

3.8 Conclusions 104

Questions for discussion 106

Bibliography 107

4 Information systems and business change $\quad 110$

Richard Thomas

4.1 Introduction 110

4.2 The organisation and appropriate information systems 110

4.3 Strategy and the value chain 115

4.4 Using technology for competitive advantage 116

4.5 Technology and strategic alignment 117

4.6 System development and business change 118

4.7 Case study: The Royal Bank of Scotland 124

4.8 Conclusions 136

Questions for discussion 137

Bibliography 138

5 The marketing conundrum

Ashok Ranchhod

5.1 Introduction 139

5.2 What is marketing? 139

5.3 Marketing history 141

5.4 The growth of direct marketing 145

5.5 The future for direct marketing 146

5.6 Technology and marketing 146

5.7 The growth of the Internet and its implications for marketing 152

5.8 Case study: direct footwear 157

5.9 Summary and conclusions 164 
Questions for discussion 173

Bibliography 173

6 The human impact of organisational change 176

Brian Thornton

6.1 Introduction: 'May you live in interesting times' 176

6.2 Management theories and their evolution 177

6.3 Personnel management and the emergence of human resourcing 179

6.4 External pressures for organisational change 181

6.5 The pursuit of flexibility 186

6.6 Organisational changes and their human impact 188

6.7 Case study 198

6.8 Conclusions 201

Questions for discussion 202

Bibliography 202

7 Lean production is only for the large? 204

Heather Stewart

7.1 Introduction: What is lean production? 204

7.2 Lean production: product design, development and engineering 209

7.3 Lean production: supply 211

7.4 Lean production: manufacture 213

7.5 Lean production: selling and distribution 215

7.6 Lean production: research and development 217

7.7 Lean production: the employees 218

7.8 Case study of lean production: Johnson \& Johnson

Orthopaedics 221

7.9 Conclusions 230

Questions for discussion 232

Bibliography 233

8 EU environmental policy and business 235

Adrian Webb

8.1 Introduction 235

8.2 The relationship between environmental policy and policy as a whole in the EU 236

8.3 The EU approach to waste and the case of the packaging directive 243

8.4 The packaging directive and the beverage cartons industry 246

8.5 The implications for Scandinavia and its paper industry 251

8.6 The paper industry response: a case history of Korsnäs $\mathrm{AB}$, Gävle 254

8.7 Conclusions 262

Questions for discussion 263

Bibliography 263 
9 Intellectual property law: providing protection for intangible business assets 265 Mark Wing

9.1 Introduction: What is intellectual property? 265

9.2 Changes in intellectual property law affecting the modern business 266

9.3 Preliminary matters: national laws and international standards 267

9.4 Copyright law 268

9.5 Patents 273

9.6 Trade Mark Law 281

9.7 Case study: Generic Media 287

9.8 Conclusions 291

Questions for discussion 292

Bibliography 292

10 Change in the global market: a study of UK maritime industries in transition 294

Mervyn Rowlinson

10.1 Introduction and structure 294

10.2 An overview of change in the maritime industries 295

10.3 A profile of the UK merchant maritime industries 298

10.4 The theoretical framework 305

10.5 The new international division of labour 306

10.6 Porter's contribution to understanding industrial structure and change 310

10.7 The shock waves of the era of economic liberalism 315

10.8 Case study: the decline of the port of Manchester 322

10.9 Summary and conclusions 323

Questions for discussion 324

Bibliography 324

Index $\quad 328$ 


\section{List of figures}

1.1 An organisation's environment 9

1.2 The five-forces model 10

1.3 The cultural web 12

1.4 A rich picture for Laura Ashley Plc in $1990 \quad 14$

1.5 The McKinsey Seven-S framework 15

1.6 Stakeholder power/dynamism matrix 19

1.7 Stakeholder power/interest matrix 19

1.8 Product/market development matrix 20

1.9 McKinsey's 7s framework for GDE 34

1.10 The cultural web applied to GDE 35

1.11 Stakeholder power/interest map of GDE 37

2.1 The financial services industry 51

2.2 Output allocation model for post-merger sections of a new organisation 54

3.1 Service marketing system for a high contact consumer service 86

3.2 Service flowchart 88

3.3 SERVQUAL model 93

4.1 Relationship between organisation and technology 118

4.2 Organisation chart: Royal Bank of Scotland Group 126

4.3 Operations support consultancy 127

4.4 The team theme 135

5.1 Influences on marketing 140

5.2 Direct marketing chart 147

5.3 Integrated marketing information systems 149

5.4 Three factors determining the ease of information sharing 150

5.5 Online retailing revenue forecast 154

5.6 Common problems using the (World Wide) Web 155

5.7 David Price's core business responsibilities at Clarks 159

5.8 Organisation chart: Cosyfeet 164

5.9 Potential for scale and scope economies in different service businesses 168

5.10 IT product/service map 169

5.11 Media typography based on objective characteristics 171

5.12 A model of marketing communications in a hypermedia CME 172

6.1 The flexible firm 187

6.2 Labour market flexibility in Britain: full and part time employment 191

6.3 Temporary employment $1996 \quad 194$ 
6.4 A typical flexible working day 194

8.1 Emissions and uptake of greenhouse gases in the Swedish forestry sector 253

8.2 How one million cubic metres of wood can be used 254

8.3 Chlorine consumption in the Korsnäs bleaching process 259

8.4 Chlorine consumption down to zero 260

10.1 UK shipbuilding output and employment, 1950-95 299

10.2 UK, Japanese and German shipbuilding output, 1950-95 300

10.3 UK fleet tonnage and seafaring employment, 1950-95 302

10.4 Fleet tonnages, UK, Liberia and Japan, 1950-95 303

10.5 UK ports tonnage handled and total employment, 1950-95 304

10.6 Product life-cycle, UK shipbuilding output, 1875-1995 308 


\section{List of tables}

2.1 Decline in number of building societies in last twenty-five years

2.2 Twenty leading building societies $1995 \quad 48$

5.1 Relative emphases in modernism and postmodernism 142

5.2 Mail order and home shopping's share of total retail sales 1988-93 145

5.3 Revenue projections for the Internet industry 154

5.4 Relative penetration of PCs compared with televisions, 1994-5 165

5.5 Forecast of household ownership of home computers, 1995-9 167

7.1 The major characteristics of lean production 208

7.2 The major characteristics of lean production at Johnson \& Johnson 231

8.1 Energy content of the carton (calorific value) 249

10.1 UK and US beneficially owned flag of convenience fleets 1980 and $1990 \quad 309$

10.2 Annual crew cost options for UK tanker owners 309 


\section{Preface}

'One thing is clear: we don't have the option of turning away from the future. No one gets to vote on whether technology is going to change our lives. No one can stop productive change in the long run because the marketplace inexorably embraces it. Governments can try to slow the rate of change within their own borders by restricting the use of certain technologies, but these policies risk leaving a country isolated from the world economy, preventing its companies from being competitive and its consumers from getting the latest products and the best prices.

I believe that progress will come no matter what, we need to make the best of it - not try to forestall it.'

(Bill Gates (Chairman and Chief Executive Officer, Microsoft Corporation), The Road Ahead, 2nd edn, Penguin Books, 1996)

\section{- Change as a central characteristic of modern business}

The common theme of this book is change and its impact on the business organisation. This involves exploring a number of issues such as:

- what causes change?

- how does change impact on a business and why?

- how might a business respond to existing change and anticipate potential change?

- what implications do the actions of one firm have for others in the same market, and for its consumers?

- what likely changes might be anticipated in the medium-term future?

This is not, therefore, a specialist book aimed just at the economist, business strategist or marketer. Rather its philosophy is to provide a broad-based examination of areas particularly relevant to modern business operations. It draws on a number of different specialisms and uses these to explore the issues identified above. Each chapter of this book is written by an expert in his or her field who takes theories of business behaviour to provide frameworks or models to apply to contemporary case studies. The reader may therefore use these models to evaluate business change, both in particular circumstances and generally. 
The inevitability of change and its accelerating pace makes this book essential reading for anyone interested in business theory and practice. It is aimed particularly at years two and three of undergraduate business courses and for students on MBA (Master of Business Administration) programmes. It is also very suitable for providing underpinning knowledge at NVQ (National Vocational Qualification) Levels 3 to 5, and for students at year two of HND (Higher National Diploma) courses. However, the book also offers valuable insights for the business practitioner and for the general reader who is interested in taking his or her knowledge of business behaviour further than just the financial pages of a newspaper.

\section{The structure of the book}

The market drivers of change are various and particularly include information technology. Its impact is explored in the context of the services sector of economies, particularly financial services, and in marketing. Chapters 2 and 4 examine the financial services industry while Chapter 3 explores the impact of change on the services sector of developed economies and, especially, the definition and qualities of services management. Chapter 5 discusses the influence of information technology on the promotion, distribution and sale of products.

Additionally, changes in more broad-based technology have impacted significantly on production and transport processes with the development of lean production, explored in Chapter 7 , and the replacement of traditional shipping by new cargo carriers, which Chapter 10 examines. This, in tum, has considerable implications for the labour force and has contributed to the development of human resources management as an important facet of managing a business, as discussed in Chapter 6 .

Another major market driver of change is competition. Certainly competition in the EU has become very much more significant with the near completion of the Single European Market. However, it is the global nature of competition which will be most important in the next twenty years, with its impact already to be seen in car and white-goods production and shipping. With EU economies increasingly providing services not producing goods, the impact of new technology, the global capital market and cheap labour will enable Pacific Rim competitors to compete even more in domestic markets. The nature of competition and its internationalisation and globalisation, and its impact in causing structural change in an industrial sector, is explored in a number of chapters in this book, particularly 1, 2, 4, 5, 7 and 10 .

Other change drivers, which are analysed in this text, are grounded in national and EU legislation. One area is the growth of intellectual property and the need for businesses to know their legal rights and how to defend these. This is discussed in Chapter 9. Another area is the environmental effects of business 
activities and the need for businesses to meet new legislative challenges. Chapter 8 examines this. In both cases these need to be addressed in businesses' strategies.

The other major characteristic of global competition is the impact of cultural differences. At the macro level, in spite of the moves to a global culture as characterised by mobile phones, McDonalds, speaking American English and watching Hollywood films on satellite tv, cultural diversity is significant both at UK and global levels. Most importantly for business, the influx of Japanese and South Korean direct investment into the UK and the remainder of the EU has introduced cultural differences 'at the back door' where industrial relations based on the single union plant, and other issues such as quality circles, have been absorbed into mainstream industrial life. Chapter 7 particularly explores these issues at the micro level. Chapter 1 looks at organisational culture and the use of Johnson's Cultural Web to analyse it, while Chapter 4 examines information systems and the organisational culture.

Just as a number of key themes exist in this book so a number of common analytical tools are employed by its authors. PEST/PESTLE analysis is used in Chapters 1,2 and 6 to explore the environment within which businesses operate, albeit in different contexts. In Chapter 1 it is applied to the French water company GDE, in Chapter 2 to the UK building societies sector of financial services and in Chapter 6 to human resources management.

The influence of American academic Michael Porter is strong in analysing the impact of change in two main areas. In Chapters 1, 4 and 10 it is important in terms of his Five Forces Model. In Chapter 4 this is used in the context of the Royal Bank of Scotland, while in Chapter 10 it is used to analyse the UK shipping industry. Porter's value chain analysis is used in Chapters 1 and 4 as a means of exploring how business activities add value to operations of a business and hence enable it to gain competitive advantage.

In the same way product/service differentiation strategies are used to analyse the operations of GDE in Chapter 1 and services management in Chapter 3.

The reader should bear in mind that theoretical developments seek to provide a better understanding of business behaviour. However, theory does not fit neatly into compartments which, when bolted together, give total understanding of how all businesses behave. Moreover, theories have weaknesses and are, at times, criticised for their lack of realism - a consequence of making necessary but limiting assumptions. Empirical testing of theory against reality is the accepted way of determining its relevance and validity, but this poses pitfalls in a number of areas. Data may not be available or may not be in the form required - hence proxy data must be used which may not map exactly against the theoretical requirements. Again, findings may be inconclusive leaving doubt as to the validity of the testing of the theory.

In practice, therefore, theories compete with each other, and while some may explain certain aspects of business behaviour better than others, in different areas they may be less effective. Consequently the reader must exercise critical judgement and awareness and actively pursue other theories for himself or herself to test the validity of these against those advanced in this book. 


\section{- Conclusions}

The warning of Bill Gates, that change is inevitable and unstoppable - and that we must live with it and make the best of it that we can - began this introduction. That may sound reactive and, in part, it is because change is most commonly imposed externally. However, one of the themes of this book considers the ability to adapt to such change, to take it forward and to utilise it for one's own benefit as a proactive response to such externally generated change.

It has often been said that we are now living through a second industrial revolution. The first, dating from the late eighteenth century, was based on capital instead of labour, fuelled by fossil fuels, and mass-produced goods to achieve economies of scale. The current revolution is information technology based with individualised production to achieve economies of scope. As important an output as physical goods is information. Ed Bales, Co-founder, Motorola University, USA, recently argued that 'technology (hardware and software) is now available to all corporations equally on a global basis. The competitive edge will go to the corporations that have the best people (mindware) managing the technology' (Keynote speech, 3rd 'Educational Innovation in Economics and Business' conference, Florida, December 1996). In other words, within their business environment, organisations can initiate change and gain competitive advantage.

However the ability to maintain it requires constant adaptability and, most importantly, investment in people.

So, if we do not change we stagnate - and others will overtake us, whether businesses or countries. This is the theme of this book, and the theoretical tools this book provides seek to help the exploration of this concept of change.

\section{- Acknowledgements}

As editor, my thanks go to my co-authors for their involvement in this book when higher education is having to adapt to rapid change and resource constraints, particularly time. Their enthusiasm, support and prompt response to my editorial requests has been much appreciated. Particular thanks go to Adrian Webb for stepping in to fill the gap so competently when one author withdrew at short notice. lan Taylor of the Education Development Service, Southampton Institute provided considerable help with the graphics, while Stephen Rutt, Publishing Director of Macmillan Business, was, as usual, helpful and supportive but not intrusive.

Last, but not least, on behalf of the authors who wrote this book, a sincere thanks is offered to all families who had to endure spouse, partner or parent hunched over a keyboard for long hours producing his or her chapter. This book is dedicated to them. 


\section{Notes on the contributors}

Gary Akehurst is Professor of Marketing at the University of Portsmouth Business School, Department of Business and Management. He is a Fellow of the Tourism Society, a Member of the Institute of Management and Member of the Chartered Institute of Marketing. He is also editor of the Service Industries Journal. He has published extensively in journals and as co-author of books. He has also undertaken consultancy work nationally and internationallv.

John Cross is Senior Lecturer in Strategic Management, Southampton Business School. He has recently undertaken substantial work producing a range of case studies one of which is incorporated into the chapter he has produced for this text. He was recently awarded the title of most inspirational teacher at Southampton Institute. Currently he is developing a sports management programme in conjunction with sporting professional bodies to meet industry needs.

Neil Harris is Head of Economics and Business Modelling, Southampton Business School. His research interests are European business, European economics, and business education. He has had articles published in refereed journals and has given papers at international conferences in the UK and overseas. His book European Business was published by Macmillan Business in 1996.

Ashok Ranchhod is Head of Marketing, Southampton Business School and has led the programme to develop its MBA. He has published widely in refereed journals and lectured extensively and given papers in Europe, the US and India. $\mathrm{He}$ was previously the managing director of a biotechnology company. His research interests centre around marketing and biotechnology.

Mervyn Rowlinson is Senior Lecturer in Transport Economics in the Maritime Faculty, Southampton Institute. He has delivered papers at international conferences, his work has been published in refereed journals and he has written discussion papers for the Labour Party. He is an active researcher, particularly in the fields of marine transport and small and medium sized enterprises.

Heather Stewart is Senior Lecturer in Accounting, Southampton Business School, and a management accountant. In 1994 she completed her MBA at 
Henley Management College. Her masters' dissertation was on lean production and her research forms the basis for her contribution to this volume.

Richard Thomas is Head of Academic Operations, Southampton Business School. He has published extensively, acting as series editor and writing several books in the 'Step by Step Guides' series published by Stanley Thornes. He has recently co-authored a book Business Information - Technologies and Strategies while his book Quantitative Methods for Business was published in 1997.

Brian Thornton is Senior Lecturer in Human Resource Management, Southampton Business School. A former senior local government officer, he has substantial and recent industrial experience in the field of HRM and has written a number of internal and position papers for employers.

Adrian Webb is a Consultant, part-time lecturer in Southampton Business School, and writer on European environmental, regional and transport issues. $\mathrm{He}$ has been widely published and contributes regularly to European Policy Analyst (formerly European Trends) published by the Economist Intelligence Unit Ltd. He has wide experience as a researcher, and as an administrator in local government and the water industry. He also speaks five languages.

Mark Wing is a lecturer in the Law Faculty, Southampton Institute. He is responsible for teaching intellectual property law and European Community law, especially on the LLM course in intellectual property, of which he is the course leader. 


\section{Glossary of abbreviations}

$\begin{array}{ll}\text { ABP } & \text { Associated British Ports } \\ \text { ACE } & \text { Alliance for Beverage Cartons and the Environment } \\ \text { AMA } & \text { American Marketing Association } \\ \text { APEAL } & \begin{array}{l}\text { Association Professionelle des Producteurs Européens d'Aciers } \\ \text { pour Emballages }\end{array} \\ \text { ARPA } & \text { Advanced Research Project Agency } \\ \text { ATM } & \text { Automated Telling Machine } \\ \text { BCME } & \text { Beverage Can Makers Europe } \\ \text { BPR } & \text { Business Process Re-engineering } \\ \text { CAD } & \text { Computer Aided Design } \\ \text { CAM } & \text { Computer Aided Manufacture } \\ \text { CASE } & \text { Computer Aided Software Engineering } \\ \text { CCT } & \text { Compulsory Competitive Tendering } \\ \text { CDPA } & \text { Copyright, Designs and Patents Act (1988) } \\ \text { CIM } & \text { Chartered Institute of Marketing } \\ \text { CLES } & \text { Centre for Local Economic Strategies } \\ \text { CME } & \text { Computer Mediated Environment } \\ \text { CPC } & \text { Community Patent Convention } \\ \text { CSO } & \text { Central Statistical Office } \\ \text { CTM } & \text { Community Trade Mark } \\ \text { EAA } & \text { European Aluminium Association } \\ \text { EC } & \text { European Community } \\ \text { EIS } & \text { European Information Service } \\ \text { EMAS } & \text { Environmental Management and Audit Scheme } \\ \text { ENDS } & \text { Environmental Data Services } \\ \text { EPC } & \text { European Patent Convention } \\ \text { EPOS } & \text { also EFTPOS: Electronic Funds Transmission at Point of Sale } \\ \text { EU } & \text { European Union } \\ \text { FOC } & \text { Flag of Convenience } \\ \text { FTP } & \text { File Transfer Protocol } \\ \text { GATT } & \text { General Agreement on Tariffs and Trade } \\ \text { GDE } & \text { Générale des Eaux } \\ \text { GDP } & \text { Gross Domestic Product } \\ \text { GRT } & \text { Gross Registered Tonnes } \\ \text { HRM } & \text { Human Resource Management } \\ \text { ILO } & \text { International Labour Office } \\ \text { IMVP } & \text { International Motor Vehicle Program } \\ \text { ISL } & \text { Institute of Shipping Logistics } \\ & \end{array}$




$\begin{array}{ll}\text { ISO } & \text { International Standards Organisation } \\ \text { IT } & \text { Information Technology } \\ \text { JIT } & \text { Just in Time } \\ \text { LIFO } & \text { Last in First out } \\ \text { NDLS } & \text { National Dock Labour Scheme } \\ \text { NGO } & \text { Non Governmental Organisation } \\ \text { NIC } & \text { Newly Industrialised Country } \\ \text { OECD } & \text { Organisation for Economic Cooperation and Development } \\ \text { PCT } & \text { Patent Cooperation Treaty (1970) } \\ \text { PEST } & \text { Political, Economic, Social, Technological } \\ \text { PESTLE } & \text { Political, Economic, Social, Technological, Legal, Environmental/ } \\ & \text { Ethical } \\ \text { RBS } & \text { Royal Bank of Scotland } \\ \text { ROCE } & \text { Rate on Capital Employed } \\ \text { SMEs } & \text { Small and Medium-sized Enterprises } \\ \text { SPC } & \text { Supplementary Protection Certificate } \\ \text { SWOT } & \text { Strengths, Weaknesses, Opportunities, Threats } \\ \text { TQM } & \text { Total Quality Management } \\ \text { TRIPS } & \text { Trade Related Aspects of Intellectual Property } \\ \text { TSB } & \text { Trustee Savings Bank } \\ \text { UNCTAD } & \text { United Nations Committee on Trade and Development } \\ \text { UNICE } & \text { Union of Industrial and Employers' Confederations of Europe } \\ \text { WTO } & \text { World Trade Organisation }\end{array}$

